\title{
Concomitant testicular infection by Zika virus and Schistosoma mansoni
}

BEUY JOOB ${ }^{1 *}$, VIROJ WIWANITKIT ${ }^{2}$

${ }^{1}$ Sanitation 1 Medical Academic Center, Bangkok, Thailand

${ }^{2}$ Visiting Professor, Hainan Medical University, Haikou, Hainan, China

Article received: 9/8/2017

Accepted for publication: 9/24/2017

*Correspondence:

Sanitation 1 Medical Academic Center

Bangkok - Thailand

Postal code: 10160

beuyjoob@hotmail.com

Dear Editor, the publication on "Concomitant testicular infection by Zika virus and Schistosoma mansoni" is very interesting. ${ }^{1}$ Alves et al. noted that "In endemic areas, orchiepididymis by Schistosoma should be investigate to avoid unnecessary surgeries. This patient was also infected with Zika virus." Indeed, this report is a good case study showing that the Zika virus can concurrently occur with any other infections. In tropical endemic countries, coinfection with Zika virus and other tropical disease is not uncommon and this might result in increased difficulty in diagnosis. The classic example is the concurrent infection with Zika and other mosquito-borne virus. ${ }^{2}$ In the present case, concurrent Zika virus infection and schistosomiasis does occur, but it seems to be only a coincidence without any significant clinical observation. Nevertheless, since there are some reports on the effect of Zika virus on testis in animal models, ${ }^{3,4}$ the long term follow-up of the case regarding fertility might provide some useful clinical data.

\section{References}

1. Alves LS, Estanislau C, Barreto L, Batista F, Toppa N. Concomitant testicular infection by Zika virus and Schistosoma mansoni in a Brazilian young boy. Rev Assoc Med Bras (1992). 2017; 63(6):500-3.

2. Roth A, Mercier A, Lepers C, Hoy D, Duituturaga S, Benyon E, et al. Concurrent outbreaks of dengue, chikungunya and Zika virus infections an unprecedented epidemic wave of mosquito-borne viruses in the Pacific 2012-2014. Euro Surveill. 2014; 19(41). pii: 20929.

3. Sheng ZY, Gao N, Wang ZY, Cui XY, Zhou DS, Fan DY, et al. Sertoli cells are susceptible to ZIKV infection in mouse testis. Front Cell Infect Microbiol. 2017; 7:272.

4. Griffin BD, Muthumani K, Warner BM, Majer A, Hagan M, Audet J, et al. DNA vaccination protects mice against $Z$ ika virus-induced damage to the testes. Nat Commun. 2017; 8:15743. 